\title{
Impact of Monetary Policy on Bank's Profitability: A Study on Listed Commercial Banks in Bangladesh
}

\author{
Md. Ariful Hoque \\ Assistant Professor \\ Department of Business Administration \\ International Islamic University Chittagong, Bangladesh \\ E-mail: hcuarif@gmail.com \\ Afzal Ahmad \\ Associate Professor \\ Department of Business Administration \\ International Islamic University Chittagong, Bangladesh \\ E-mail: afzaliiuc@gmail.com \\ Mustafa Manir Chowdhury \\ Associate Professor \\ Department of Business Administration \\ International Islamic University Chittagong, Bangladesh \\ E-mail: mmanir7@yahoo.com \\ Mohammad Shahidullah \\ MBA Student \\ Department of Business Administration \\ International Islamic University Chittagong, Bangladesh \\ E-mail: mohammadI5I459@gmail.com
}

Received: July 07, 2020

doi: I0.4628I/ijafr.v5i2.796
Accepted: July 30, 2020

Online Published: October II, 2020

URL: https://doi.org/I0.4628I/ijafr.v5i2.796

\begin{abstract}
Monetary policy is the policy by which the government of a country control supplies of money in an economy which is announced by the central bank for every six months. Central Bank carries out monetary policy by the banking system of a country. Central Bank uses Bank rate; Cash reserve ratio and open market operation to control the availability of funds in an economy. Within these three instruments, the cash reserve ratio is directly linked to the commercial bank's profitability. Every commercial bank maintains a cash reserve ratio against their demand \& time deposits. Being changes in the cash reserve ratio banks profit level may increase or decrease. The prime intention here is to show the impact of monetary policy, especially Cash Reserve Ratio on the commercial bank's profitability. This study covers only listed commercial banks in Bangladesh. As sample researcher purposively selected I5 listed commercial banks that have available information. Results revealed that CRR negatively related to Return On Assets (-0.1 133), Return On Equity (-0.0577) as well as Return On Investment (-0.0504). This means the bank's profitability declined due to the increase in cash reserve ratio (CRR). Again regression analysis outlined that the cash reserve ratio negatively impacts on the profitability of studied commercial banks in Bangladesh, which is statistically significant at the I0\% level. Researchers proposed that Bangladeshi commercial banks will design their profitability plan by considering monetary policy tools, particularly the Cash reserve ratio.
\end{abstract}

Keywords: Monetary Policy, Cash Reserve Ratio, Profitability. 


\section{Introduction}

The Banking sector is the prime participant in the financial system of any country in this world. Economic development and growth in any country highly relay on the robust banking system of the respective countries. To become a sound banking system, participants or commercial banks must ensure liquidity, profitability and, efficiency. The main activities of commercial banks are to collect deposits from surplus sectors and distribute funds in deficit sectors. For smoothing the banking activities, banks should ensure proper trade-off between profitability and liquidity. Commercial banks require profitability for the long-run serving in the market and liquidity necessary for short-term surviving in the competitive market. Profitability confirms the bank's long-term solvency and liquidity ensures short-term solvency. The monetary policy indicates the amalgamation of measures arrange to manage the supply, outlay \& value of money in a particular territory. It can also define as the mechanism of overseeing the volume of funding facilities to keep stability in price \&budgetaryprogress in a country (Chowdhury, Hoffman, \& Schabert, 2003). Again in another way, monetary policy attributes to the response of a country's central bank to control the volume of currency with the help of various instruments like open market operation; cash reserve ratio and bank rate, moral suasion, forthright monitoring of bank's credit, and sincere supervision of lending \& borrowing interest rate (Loayza, \& Schmidt-hebbel, 2002). The short-term policy, which is promulgated by the central bank in every six months of the respective countries, is acquainted as monetary policy. In any country monetary policy is formulated and implemented by their respective central bank, which is implemented through the banking avenue. The aims \& objectives of implementing the monetary policy are to keep inflation at a tolerable level, protecting the purchasing power of funds, adequate employment, and ensuring the sustainability of economic advancement. Either monetary policy may be flexible or rigid reliance on the comprehensive goal of the policy. If monetary authorities want to boost up the flow of currency or funds in an economy, then flexible monetary policy is followed and vice verse.

In Bangladesh, the banking industry has grown rapidly during the last four decades, which creates intense competition among incorporated banks. Sustainability of the banking industry's performance highly depends on the stable political situation, macroeconomic stability, strongly monitoring on banking institutions to confirm competent compliance of industry with the discreet supervisory and legislative structure. Recently banking system in Bangladesh confronts some burning issues like liquidity, solvency, and efficiency that may notably dominate the performance of commercial banks. The banking sector recognizes as a vital part of the economic condition of Bangladesh. As a central authority of the banking sector, Bangladesh bank has been applying the cash reserve ratio as a device of monetary policy to reinforce money circulation in the economy. In the banking sector, instead of open market operation, the central bank used a cash reserve ratio to oversight the fund's dissemination in a country. Cash Reserve Ratio is imposed on the bank's time and demand deposits that must comply with every registered commercial bank's. Cash reserve ratio (CRR) is considered as a tax on bank deposits (Abidi, \& Lodhi, 2015). Any revisions in CRR may impact the banking sector's availability of funds in the hand of the bank for supply credit in the economy, thereby manipulating the bank's financial performance. So, the main intension of this research is to assess the impact of monetary policy on the deviation of profitability in some picked private commercial banks in Bangladesh. The researchers also calculate Pearson's co-relationship coefficient between commercial bank's profitability \& monetary policy for study purpose.

\section{Literature Review}

The banking sector is evaluated as a blood of an economy due to its noticeable contribution toward the channelizing funds, which ensures industrialization in a country. Monetary policy acts as an effective tool to control money circulation in an economy and thereby to ensure the stability of a currency's purchasing power. So there is a good understanding between the monetary policy and the bank's profitability. Followings are relevant literature both within $\&$ outside the country on the studied topics:

Rao (2006) examined the influence of monetary policy on the profitability of Indian banks. The researcher considers Bank Rate, SLR, and CRR as a proxy of monetary policy as well as ROA \& ROE as a proxy of bank profitability. Results confessed that lending rates have an agreeable tie-up with banks' profit that means increasing in lending rates will improve the profitability position of the banks. In public sector banks, after incorporating CRR, SLR, and bank rate regression coefficient is not significant to describe the link-up between the bank's profitability and monetary policy instruments. It is recommended that the banking sector should be regulated and controlled based on a rigid credit policy pursued by the Reserve Bank of India to minimize the inflationary pressures. Younus and Akhta (2009) studied the implication of Statutory Liquidity Requirement (SLR) as a monetary policy device in Bangladesh. Applying descriptive analysis crafts, researchers have shown that SLR has surfaced sporadic reforms and previous testimony outlined that decreases in SLR have a favorable influence on bank credit as well as investment narrowly earlier I990s. Statutory liquidity requirement (SLR) and Cash Reserve Requirement (CRR) were identified as crucial instruments for reducing inflation. Researchers also outlined that most of the time, Bangladesh Bank has applied open market operations (OMO) instead of altering the Bank Rate and SLR as devices of monetary policy in conformity its marketadjusted approach. Ajayi and Atanda (2012) interrogated the impact of monetary policy devices on banks achievement to determine the presence of lengthy affiliation for the time being 1980-2008 in Nigeria. The Engle-granger dual-stage co-integration approaches had been endorsed. The result revealed that bank rate, inflation rate, as well as interest rate are credit embellishing, at the same time liquidity ratio \& cash reserves ratio have adversely enforced on aggregate outstanding credit of banks. Again only cash set aside system, as well as interest rate, have traced out to be statistically meaningful at a 5\% level. Finally, the researcher 
recommended monetary policy devices are not impressive to augment credit supply in the distant future, whilst banks full credit is higher sensible to cash reserve system. Haiying Pan, Song, Wang, and Hu (20I2) investigates the effect of continual raises of the reserve requirement ratios by the people's bank of china through Vector Auto-Regression (VAR), the Johansen co-integration test, along with the Granger causality test. Researchers incorporate monthly numerical data from January 2006 to March $201 \mathrm{I}$ for study purposes. Researchers found that revision of reserve ratio does not any direct impact on managing additional liquidity, averting inflation as well as supervising the lending service. Again, RRR has an everlasting but negligible negative pressure on fund supply and loan scale. Naseem (2012) studied the factors contributing to the profitability of the banking sector in Pakistan. The researcher also testified about the relationship between the bank's profitability and macroeconomics factors, along with bankspecific characteristics. The results outlined that institutional and country-level factors have robustly exerted on the profitability of the comprehensive banking sector in Pakistan. Banks Assets, credit, Deposits, and country-level aspects like, economic amelioration, inflation, and stock market capitalization are assumed to be a driving force of Pakistani banks for better profitability. Khan and Sattar (20I4) examine the influence on interest rate modification on the profitability of four dominant profit-making banks in Pakistan. Within this inspection, researchers considered the bank's profitability as explained variable and interest rate is the explanatory variable. Panel data for five years is incorporate from 2008 to 2012. Pearson's correlation is applied to assess the connection between interest rate revisions and the commercial bank's profitability. Results have shown that Pearson's correlation between interest rate changes and the bank's profitability is -0.69 , which means there is a strong negative correlation. Abidi and Lodhi (2015) assess the impact of modifications in reserve requirement on the profitability of commercial banks in Pakistan. In this study, researchers incorporate 17 commercial banks as a sample, moreover considered I0 years' time-series data from 2005 to 20I4. Reserve requirement is the explanatory variable, as well as profitability, is the explained variable in this study. Again CRR is the proxy of reserve requirement and returns on assets \& return on equity is the surrogate of commercials banks profitability. For analyzing collected data, researchers utilized a person's correlation followed by simple linear regression. Results reveal that there is an unfavorable interrelationship between CRR \& bank's profitability (ROA: -.35, ROE: -.022) in Pakistan. Regression result shows that changes in CRR adversely influence the bank's profitability. That means as the state bank of Pakistan will increase CRR, ROA \& ROE will decrease for commercial banks and vice versa. Udeh (20I5) investigates the effect of monetary policy tools on the profitability of Nigerian commercial banks' special reference to Zenith bank experience. The researcher incorporates eight years of time-series data of Zenith bank plc in this study from 2005 to 20I2. The profitability of Zenith bank plc is expressed by profit before tax and liquidity rate, interest rate cash reserve rate $\&$ lowest rediscount rate are the monetary policy appliances. For analyzing data, the Pearson product-moment correlation approach was used as well as a testing hypothesis; the researcher applies t-test statistics. The researcher found that the lowest rediscount rate has a highly positive correlation with earnings before tax of Zenith bank plc and thereby positively affect on the profitability of the said bank. The other factors, such as liquidity rate; interest rate $\&$ cash reserve rate do not significantly impact the sample bank's profitability. The researcher recommended that Nigerian commercial banks enhanced their future profitability plans by ignoring liquidity rate; interest rate $\&$ cash reserve rate as a device of monetary policy. Yesmine and Bhuiyah (2015) studied the determinants of the financial performance of some selected private and nationalized commercial banks in Bangladesh. Researchers selected 10 private and 4 nationalized commercial as a sample in this study. Panel data of 7 years from 2008 to 2014 has used in this research. The financial performance that is represented through return on assets (ROA) is the dependent variable as well as bank's size, credit risk; asset utilization, liquidity, operational efficiency, and capital sufficiency are explanatory variables. Multiple regression analysis is applied to uncover the factors influencing on the financial performance of studied commercial in Bangladesh. The inspection exposed that the bank's financial performance is supportively affected by assets utilization \& operational efficiency as well as negatively affected by credit risk. Researchers recommended that commercial banks in Bangladesh develop their financial performance by significantly focusing on asset utilization, credit risk, and operational efficiency. Oganda, Mogwambo and Otieno (2018) scrutinized the stress of cash reserve on the performance of commercial banks in Kenya. As sample researchers considered two commercial banks operated in Kenya and panel data for ten years are included in this study from 2007 to 2016. Researchers also considered the cash reserve of the bank against their deposits \& liabilities as of the explanatory variable and commercial banks performance as a dependent variable which is represented by ROA, ROE, and NIM. Descriptive, along with inferential statistics, are employed to examine data which is guided by the correlation matrix. SPSS Version 2I software was employed to develop descriptive together with inferential statistics. Results reveal that cash reserve have significantly strong negative correlation with all the proxy $(\mathrm{ROA}=$ $0.767(\mathrm{p}<0.0 \mathrm{I}), \mathrm{ROE}=-0.756(\mathrm{p}<0.05), \& \mathrm{NIM}=-0.777(\mathrm{p}=<0.0 \mathrm{I}))$ of the commercial banks profitability for national bank of Kenya. In the case of equity bank of Kenya, cash reserve has an insignificant negative relation with ROA (-0.03), significant positive correlation with ROE (0.672), and lower positive relation with NIM (0.267). Researchers recommended that cash reserve should minimize to boost up financial performance of commercial banks in Kenya.

\section{Statement of the Problems}

Commercial banks are a crucial pillar or component of the financial system of Bangladesh because they act as vanes in the money dissemination of our economy. Generally, the development of an economy highly relies on the healthy $\&$ sound banking system of the country. Robust banking system performs an essential role in efficient\& effective allocation as well as utilization of credit 
$\&$ funds (Haque \& Tariq, 2012). In Bangladesh supply of money \& funds is controlled by Bangladesh bank through various monetary policy apparatuses like CRR, bank rate inclusive of open market operation. Existence of commercial banks relies on a sufficient amount of earnings which is known as profitability. For making an adequate amount of profit, commercial banks must ensure smooth banking services for which they require a sufficient amount of funds. Mainly commercial banks earn most of their income from credit which depends on large funds. In the banking sense, availability of funds is known as liquidity which is controlled by Bangladesh bank through various monetary policy instruments. So it is seen that commercial bank's profitability is highly persuaded by monetary policy appliances like Cash Reserve Ratio, open market operation, in addition to bank rate as external or macroeconomic factors. As per Bangladesh bank information cash reserve ratio was 5.5\% up to June 20I4, 6.5\% from I5 June 2014 to I4 April 2018 and again 5.5\% from I5 April 2018 to till now. Money circulation within the banking channel is the main ingredient for economic upliftment and growth of a developing country like Bangladesh. Mobilization of funds in Bangladesh is controlled by adequately formulating and implementing the monetary policy. A country's monetary policy is like working capital of a business firm. If a firm fails to deal with working capital tactfully, then its profitability level may reduce as well as may face various kinds of difficulties. Like this, if the government of a country is not able to treat monetary policy efficiently, then financial institutions' special bank may confront various challenges like a liquidity crisis, decreased profitability etc. So it is estimated that monetary policy instruments must have a stress on the commercial bank's benefit of a country. As per the researcher's knowledge, there is no empirical study that assesses the impact of monetary policy apparatuses, particularly the Cash reserve ratio on the bank's profitability in Bangladesh. So this study is the researchers' simple endeavored to fulfil this research gap in the banking sectors of Bangladesh.

\section{Research Methodology}

The methodology is a scientific process of solving the research problems systematically. Various steps of research methodology must be followed chronologically to complete a research study correctly. Different phases of research methodology are research design, sample selection, variables specification, identifying \& collecting data, econometric model specification and finally determining accurate statistical tools \& techniques to analyze collected data.

\section{I Sample Size}

The Population of this study is the banking industry in Bangladesh. As per Bangladesh Bank report, there are 60 registered schedule commercial banks in Bangladesh. Among these 60, only 30 commercial banks are incorporated in the stock market. For this study researcher purposively selects 15 registered private commercial banks as a sample based on their availability of data over the study periods.

\subsection{Variable Specification}

Within this study, the researcher considers monetary policy as the explanatory variable, which is represented by cash reserve ratio (CRR), statutory liquidity ratio (SLR), and Bank rate (BR). Commercial bank's profitability is the dependent variable where ROA, ROE \& ROI are the proxies of it.

\subsection{Sources of Data}

This research was an empirical study, so the researchers require only secondary data which are collected from the Dhaka stock exchange and respective bank's annual reports. Data on CRR and Bank rate are collected from Bangladesh bank. For this study, the researcher uses panel data for eight years, from $201 \mathrm{I}$ to 2018.

\subsection{Data Analysis Tools and Techniques}

For assessing the variation of bank's profitability due to monetary policy, regression analysis is used. Collected secondary data of this study purpose are analyzed with the help of strata I2.

\subsection{Model Specification}

The cash reserve ratio is a part of the statutory liquidity ratio. If CRR is isolated from SLR over the study period, it is constant like bank rate. SLR and bank rate do not influence on the dependent variable due to constant rate over the sample periods for that reason these variables are omitted from this study. So a simple linear regression model is formulated and applied instead of multiple regression models.

Model-I:

$\mathrm{ROA}_{\mathrm{it}}=\alpha+\beta_{\mathrm{I}} \mathrm{CRR}+\mathrm{e}_{\mathrm{it}}$

Model-2:

$\mathrm{ROE}_{\mathrm{it}}=\alpha+\beta_{\mathrm{I}} \mathrm{CRR}+\mathrm{e}_{\mathrm{it}}$

Model-3:

$\mathrm{ROI}_{\mathrm{it}}=\alpha+\beta_{\mathrm{I}} \mathrm{CRR}+\mathrm{e}_{\mathrm{it}}$ 
Here,

$\mathrm{ROA}=$ return on assets,

$\mathrm{ROE}=$ return on equity

$\mathrm{ROI}=$ return on Investment

$\mathrm{CRR}=$ cash reserve ratio

$\mathrm{BR}=$ bank rate

$\alpha=$ constant

$\beta_{\mathrm{I} \&} \beta_{2}=$ co-efficient of respective explanatory variables

$e_{i t}=$ Error term or unexplained portion of dependent variable by explanatory variables

Among these three models, the only first model is incorporated because of the fitness of the model. Remaining two models are not statistically fit to clarify the dependent variable in this analysis.

\subsection{Research Hypothesis}

HIA: Monetary policy has a statistically significant correlation with the commercial bank's profitability in Bangladesh.

$\mathrm{H}_{2 \mathrm{~A}}$ : Monetary policy has a statistically significant negative impact on the commercial bank's profitability in Bangladesh.

\section{Analysis and Discussion}

TableI. Descriptive statistics

\begin{tabular}{llllllll}
\hline Variable & Observation & Mean & Std. Dev. & Min & Max & Skewness & Kurtosis \\
\hline ROA & I20 & I.08 & 0.46 & $0.0 \mathrm{I}$ & 2.52 & $0.6 \mathrm{I}$ & 3.13 \\
\hline ROE & I20 & I2.25 & 4.34 & 0.13 & 24.77 & 0.36 & 3.24 \\
\hline ROI & I20 & 6.65 & 4.45 & 0.48 & 22.6 & 0.74 & $3.4 \mathrm{I}$ \\
\hline CRR & I20 & 6 & 0.50 & 5.5 & 6.5 & 0 & I \\
\hline
\end{tabular}

Source: Researchers own analysis

Either research work is done on qualitative or quantitative data. Descriptive statistics is essential due to determining normality of data, selecting a parametric or non-parametric test, and identifying outliers in the data set. In the above table, it is seen that the mean value of return on equity (12.25) is larger comparer to remaining variables, i.e. ROA (I.08), ROI (6.65), and CRR (6). In descriptive statistics, standard deviation measures the distance of various observations from the mean or average value. As per standard deviation, there is more consistency in the observations of return on assets $(0.46)$ compare to remaining variables, but they also have a tolerable level of consistency. Both values of the Skewness and Kurtosis indicate normality of data set where values of Kurtosis is near about 3 and Skewness is less than I or near to zero.

Table 2. Correlation Matrix

\begin{tabular}{|c|c|c|c|c|}
\hline & $\mathrm{ROA}$ & $\mathrm{ROE}$ & ROI & CRR \\
\hline $\mathrm{ROA}$ & $\mathrm{I}$ & & & \\
\hline $\mathrm{ROE}$ & $\begin{array}{c}0.8634^{\text {tx }} \\
(0.0000)\end{array}$ & $\mathrm{I}$ & & \\
\hline ROI & $\begin{array}{l}0.4596^{*} \\
(0.0000)\end{array}$ & $\begin{array}{l}0.3889^{\text {th }} \\
(0.0000)\end{array}$ & $\mathrm{I}$ & \\
\hline CRR & -0.1133 & -0.0577 & -0.0504 & $\mathrm{I}$ \\
\hline
\end{tabular}

Source: Researchers own analysis

Correlation measures the nature and level of the interrelationship between two variables. In the above correlation matrix return on assets (ROA), return on equity (ROE) and return on investment (ROI) represents the profitability of picked commercial banks in Bangladesh which is also dependent variable in this inspection. On the other hand, the cash reserve ratio (CRR) is the monetary policy mechanism considered as the explanatory variable here. From the correlation matrix, it is observed, the relationships among all the explained variables are positive and statistically significant at the I0\% level. But CRR adversely related to ROA (-0.1 133), ROE (-0.0577) as well as ROI (-0.0504) which is not statistically significant. That means, if CRR increases I\% ROA will decrease I I.33\%, ROE will decline by 5.77\%, and ROI will drop 5.04\%. From this analysis, it is found that the 
Cash reserve ratio as monetary policy instruments negatively related to the profitability of selected commercial banks in Bangladesh which is consistent with the findings of Abidi and Lodhi (2015) and Oganda et al. (2018). So researchers able to accept first formulated hypothesis in this study.

\section{I Regression Model}

Researchers only run the first model where ROA is the proxy of studied private commercial bank's profitability. The remaining two models are not run because these models are not statistically fit to explain depend on a variable by independent variable.

$\mathrm{ROA}_{\text {it }}=\alpha+\beta_{\mathrm{I}} \mathrm{CRR}+\mathrm{e}_{\mathrm{it}}$

Table 3. Regression analysis

\begin{tabular}{cc}
\hline Number of obs & I20 \\
\hline F( I, II8) & 2.05 \\
\hline Prob $>$ F & 0.108 \\
\hline R-squared & 0.0128 \\
\hline Adj R-squared & 0.0045 \\
\hline Root MSE & 0.4629 \\
\hline
\end{tabular}

\begin{tabular}{ccccccc}
\hline roa & Coef. & Std. Err. & $\mathrm{t}$ & $\mathrm{P}>\mathrm{t}$ & \multicolumn{2}{c}{$\begin{array}{c}\text { 95\% Conf. } \\
\text { Interval] }\end{array}$} \\
\hline crr & -0.10467 & $0.0845 \mathrm{I} 4$ & -1.24 & 0.108 & -0.27203 & 0.062694 \\
\hline cons & 1.707333 & 0.508842 & 3.36 & 0.001 & 0.699688 & 2.714979 \\
\hline
\end{tabular}

In this above regression model, ROA is the explained variable, and CRR is the explanatory variable. Results indicate that CRR negatively impacts on the ROA, which is statistically near to be significant. ROA decreases I0.47\% due to I\% increases in CRR, which refers to studied private commercial bank's profitability decline $10.47 \%$ as CRR increases by I\%. The F-value of this model is 2.05, which indicate the fitness of the set model. From the calculation, it is also observed that the value of the adjusted $\mathrm{R}^{2}(0.45 \%)$ is consistent with the value of $\mathrm{R}^{2}(\mathrm{I} .28 \%)$ which also ensures the acceptability of the set model. $\mathrm{R}^{2}$ value in this model is $\mathrm{I} .28 \%$ which means as explanatory variable CRR only liable for $\mathrm{I} .28 \%$ variation of the ROA, which represents the profitability of studied commercial banks in Bangladesh. The model only explained the insignificant percentage of commercial banks profitability because it is influenced by a large number of micro or institutional level variables like efficiency, liquidity, portfolio quality, the volume of investment, credit or investment recovery, competitive market position, etc. and macro or countrylevel variables such investment environment, political stability, inflation, economic condition, fiscal policy, etc. From the above discussion, the researchers also accept the second hypothesis, which means cash reserve ratio impact the profitability of selected commercial banks in Bangladesh. The finding of this study is consistent with Ajayi and Atanda (2012) and Abidi and Lodhi (20I5) as well as contradict with Rao (2006) and Udeh (20I5).

\section{Conclusion}

The banking system is the heart of an economy which is essential for a country to ensure smooth circulation of funds. The banking sector sustainable performed its functions in the long-run in an economy through ensuring profitability. On the other hand, monetary policy is the short period government policy which purpose is to keep inflation in a tolerable level through controlling supply currency in a country with assist of Cash reserve ratio, open market operation, and bank rate. In the banking sense, availability of funds is known as liquidity which is controlled by Bangladesh bank through various monetary policy instruments. So the main objective of this study is to assess the impact of cash reserve ratio on the profitability of some selected private commercial banks in Bangladesh. Researchers consider the monetary policy as an explanatory variable which is pictured by cash reserve ratio (CRR), and Commercial bank's profitability is the dependent variable where ROA, ROE \& ROI are the proxies of it. Researchers purposively select I5 registered private commercial banks as a sample where eight years of unbalance panel data are used from 20II to 2018. Researchers apply a simple linear regression model to assess the impact of cash reserve ratio on the profitability of commercial banks in Bangladesh. Person's correlation shown that CRR adversely related to ROA (-O.I I33), ROE $(-0.0577)$ as well as ROI (-0.0504), which is not statistically significant. This is steady with the findings of Abidi and Lodhi (2015) and Oganda et al. (2018). Results also revealed that CRR negatively impacts on the ROA, which is statistically meaningful at the 10\% level. This finding also similar to Ajayi and Atanda (2012) and Abidi and Lodhi (2015) as well as contradict with Rao (2006) and Udeh (20I5). So researchers recommended Bangladeshi commercial banks should design their profitability plan by considering monetary policy appliances, particularly the Cash reserve ratio. The research can be extended by incorporating

- Relevant micro and macro variables that significantly influence the financial performance of financial institutions like commercial banks, non-bank financial institutions in Bangladesh

- More balanced longitudinal data

- Qualitative factors 


\section{References}

Ajayi, F. O., \& Atanda, A. A. (2012). Monetary policy and bank performance in Nigeria: A two-step cointegration approach. African Journal of Scientific Research, $9(\mathrm{I}), 462-476$.

Abidi, F. S., \& Lodhi, S. (2015). Impact of Changes in Reserve Requirement on Banks Profitability: A Case of Commercial Banks in Pakistan. European Journal of Business and Management, 7, I-6.

Chowdhury, I., Hoffmann, M., \& Schabert, A. (2006). Inflation dynamics and the cost channel of monetary transmission. European Economic Review, 50(4), 995-1016.

Haque, A., \& Tariq, A. (2012). Efficiency of banks in Pakistan: A non-parametric approach. Business and Economic Research, 2(I).

Khan, W. A., \& Sattar, A. (20I4). Impact of interest rate changes on the profitability of four major commercial banks in Pakistan. International journal of accounting and financial reporting, 4(I), I42-I54.

Loayza, N., \& Schmidt-Hebbel, K. (2002). Monetary policy functions and transmission mechanisms: an overview. Series on Central Banking, Analysis, and Economic Policies, no. 4.

Naseem, I. (20I2). The Profitability of Banking Sector in Pakistan. Science Series Data Report, 42-53

Oganda, A. J., Mogwambo, V. A., \& Otieno, S. (2018). Effect of Cash Reserves on Performance of Commercial Banks in Kenya: A Comparative Study between National Bank and Equity Bank Kenya Limited. International Journal of Academic Research in Business and Social Sciences, 8(9), 685-704.

Pan, H., Song, H., Wang, Y., \& Hu, Y. (2012). Analysis of the Effects of Frequent Increases of the Reserve Requirement Ratio by the People's Bank of China. Modern Economy, 3(2), 229-236.

Rao, P. (2006). Monetary policy: Its impact on the profitability of banks in India. International Business \& Economics Research Journal (IBER), 5(3).

Udeh, S. N. (20I5). Impact of monetary policy instruments on profitability of commercial banks in Nigeria: Zenith bank experience. Research Journal of Finance and Accounting, 6(10).

Yesmine, S., \& Bhuiyah, M. S. Y. (2015). Determinants of banks' financial performance: A comparative study between nationalized and local private commercial banks of Bangladesh. International Journal of Business and Management Invention, 4(9), 33-39.

Younus, S., \& Akhtar, M. (2009). The SLR as a monetary policy instrument in Bangladesh. IMF Occasional.

\section{Appendices}

Appendix-A: Table 4. Cash Reserve Ratio (CRR \%)

\begin{tabular}{lcccccccc}
\hline Year & $201 \mathrm{II}$ & 2012 & 2013 & 2014 & 2015 & 2016 & 2017 & 2018 \\
\hline CRR & 5.5 & 5.5 & 5.5 & 6.5 & 6.5 & 6.5 & 6.5 & 5.5 \\
\hline
\end{tabular}

Appendix-B: Table 5. Return on Assets (ROA \%)

\begin{tabular}{|c|c|c|c|c|c|c|c|c|}
\hline Year & $20 I I$ & 2012 & 2013 & $20 I 4$ & 2015 & 2016 & 2017 & 2018 \\
\hline \multicolumn{9}{|c|}{$\begin{array}{c}\text { Name of the } \\
\text { Bank }\end{array}$} \\
\hline AAIBL & 2.06 & $\mathrm{I} .3$ & $\mathrm{I} .3 \mathrm{I}$ & I.I & 1.08 & 1.23 & 0.99 & 0.73 \\
\hline ABBL & 0.93 & 0.88 & 0.53 & 0.54 & 0.48 & 0.44 & 0.10 & 0.27 \\
\hline BASIAL & 1.72 & 0.7 & 0.96 & 1.28 & 1.26 & 0.65 & 0.76 & 0.76 \\
\hline BRACBL & 1.36 & 0.35 & 0.78 & 1.09 & I.I3 & I.89 & 2.02 & 1.87 \\
\hline CITYBL & 2 & 0.6 & 0.7 & $\mathrm{I} .4$ & I.9 & $\mathrm{I} .7$ & $\mathrm{I} .4$ & 0.7 \\
\hline DBL & 2.22 & 0.59 & 1.39 & 1.34 & 0.66 & 0.77 & 0.69 & 0.56 \\
\hline$\overline{E B L}$ & 2.52 & 1.72 & 1.68 & 1.28 & 1.23 & 1.33 & 1.04 & I.I5 \\
\hline EXIMBL & 1.65 & $\mathrm{I} .45$ & 1.06 & I.I5 & 0.84 & 1.09 & 1.06 & 0.66 \\
\hline IBBL & 1.35 & 1.27 & 0.96 & 0.67 & 0.44 & 0.59 & 0.55 & 0.64 \\
\hline NCCBL & 2.12 & I.I4 & $0.9 \mathrm{I}$ & I.I6 & 0.97 & $\mathrm{I} .3$ & 0.94 & 0.82 \\
\hline MTBL & $0.6 \mathrm{I}$ & 0.39 & 0.59 & 0.88 & 1.04 & 0.94 & 1.08 & 0.82 \\
\hline SEBL & 1.32 & 0.95 & 1.64 & 1.67 & 1.23 & 0.88 & 0.37 & 0.68 \\
\hline STDBL & 1.83 & 1.57 & 0.99 & 1.06 & 1.27 & 0.76 & 0.75 & 0.67 \\
\hline
\end{tabular}




\begin{tabular}{lccccccccc}
\hline UCBL & $\mathrm{I} .97$ & 0.84 & $\mathrm{I} .4 \mathrm{I}$ & $\mathrm{I} .49$ & $\mathrm{I} .42$ & 0.84 & 0.7 & 0.66 \\
\hline UTTARABL & $\mathrm{I} .7$ & $\mathrm{I}$ & 0.99 & 0.99 & 0.99 & 0.94 & 0.87 & 0.9 \\
\hline
\end{tabular}

Appendix-C: Table 6. Return on Assets (ROE \%)

\begin{tabular}{|c|c|c|c|c|c|c|c|c|}
\hline Year & $20 I I$ & 2012 & 2013 & 2014 & 2015 & 2016 & 2017 & 2018 \\
\hline \multicolumn{9}{|l|}{$\begin{array}{c}\text { Name of the } \\
\text { Bank }\end{array}$} \\
\hline AAIBL & 18.34 & 13.85 & I4.I5 & $\mathrm{I} 2.8$ & 12.82 & I5.7 & $\mathrm{I} 4.07$ & $\mathrm{I} 0.46$ \\
\hline ABBL & 9.25 & $9.3 \mathrm{I}$ & 6.13 & 6.95 & 6.03 & 5.68 & $\mathrm{I} .3$ & 3.74 \\
\hline BASIAL & 19.61 & $7 . I I$ & 10.55 & $\mathrm{I} 4.09$ & $\mathrm{I} 4.36$ & 8.13 & $\mathrm{IO} .2 \mathrm{I}$ & $\mathrm{I} 0.2 \mathrm{I}$ \\
\hline BRACBL & 17.9 & 5.47 & $\mathrm{I} 2.6$ & I4.I I & $\mathrm{I} 3.32$ & 22.16 & 22.14 & 19.25 \\
\hline CITYBL & $\mathrm{I} 3.7$ & 4.3 & 7.3 & 8.2 & I5.9 & 19 & $\mathrm{I} 8.3$ & $\mathrm{I3} .04$ \\
\hline DBL & 23.49 & 7.24 & I6.2I & 15.92 & $\mathrm{I} 0.74$ & I0.15 & $9.2 \mathrm{I}$ & 8.18 \\
\hline$\overline{E B L}$ & 19.03 & $\mathrm{I} 4.44$ & $\mathrm{I} 4.44$ & I0.93 & 10.95 & $\mathrm{I} 2.94$ & II.4I & 13.83 \\
\hline EXIMBL & $\mathrm{I} 4.9 \mathrm{I}$ & 13.86 & 10.27 & II.34 & 8.68 & II.78 & 12.19 & 8.35 \\
\hline IBBL & 17.42 & 13.42 & 11.36 & 8.85 & 7 & 9.28 & 9.63 & II.07 \\
\hline NCCBL & 18.98 & II.8I & 8.96 & 10.87 & 9.12 & $\mathrm{I} 2.9 \mathrm{I}$ & 10.49 & 10.45 \\
\hline MTBL & 8.84 & 6.8 & II.I5 & $\mathrm{I} 5.74$ & 17.4 & I5.6I & I8.35 & 13.85 \\
\hline SEBL & 10.47 & 8.42 & 16.2 & $\mathrm{I} 6.5 \mathrm{I}$ & 11.86 & 9.06 & 4.46 & 9.17 \\
\hline STDBL & 20.75 & 17.67 & II.56 & $\mathrm{I} 2.27$ & I3.9I & 8.66 & 9.24 & 8.47 \\
\hline UCBL & 24.77 & 9.29 & $\mathrm{I} 5.85$ & 17.07 & 16.54 & 10.24 & $9.3 \mathrm{I}$ & 9.27 \\
\hline UTTARABL & I7.I3 & 12.62 & $\mathrm{I} 2.27$ & I I.4I & II.42 & I I.47 & II.2 & II.66 \\
\hline
\end{tabular}

AAIBL $=$ Al-Arafah Islamic Bank Ltd.

$\mathrm{ABBL}=\mathrm{AB}$ Bank Ltd.

BASIAL = Bank Asia Ltd.

BRACBL $=$ BRAC Bank Ltd.

CITYBL = The City Bank Ltd.

DBL = Dhaka Bank Ltd.

$\mathrm{EBL}=$ Eastern Bank Ltd.

EXIMBL = EXIM Bank Ltd.

IBBL = Islamic Bank Bangladesh Ltd.

NCCBL = NCC Bank Ltd.

MTBL $=$ Mutual Trust Bank Ltd.

SEBL = Southeast Bank Ltd.

STDBL $=$ Standard Bank Ltd.

UCBL = United Commercial Bank Ltd.

UTTARABL = Uttara Bank Ltd.

\section{Copyrights}

Copyright for this article is retained by the author(s), with first publication rights granted to the journal. This is an open-access article distributed under the terms and conditions of the Creative Commons Attribution license (http://creativecommons.org/licenses/by/4.0/). 